\title{
Ritualistic Nudity. Dressing AND UNDRESSING IN OvID's FASTI
}

DESNUdEZ RITUAL. Vestirse y DESVESTIRSE

EN los Fasti DE Ovidio

TAMmY Di-Giusto

University Of AdELAIDE

tammy.di-giusto@adelaide.edu.au

\section{Abstract}

Ovid's Fasti is a work of significance in defining the relationship between religious identity and clothing. This article examines the interplay between dressing and the divine and considers the key role that dressing, undressing, and nakedness plays in the worship of certain deities in the Fasti. Clothing and nudity are intimately linked to the changing nature of the socio-political landscape in the worship of these deities. Contemporary rites in $1^{\text {st }}$ cent. Rome relate

\section{Resumen}

Los Fasti de Ovidio son una obra de gran importancia para analizar la relación existente entre la identidad religiosa y la vestimenta. Este artículo examina la interacción entre el vestir y lo divino y aborda el papel clave que desempeña la vestimenta, el desvestirse, y la desnudez en el culto de ciertas deidades en los Fasti. La ropa y la desnudez están íntimamente ligadas a la naturaleza cambiante del panorama sociopolítico en el culto de estas divinidades. Los rituales con- 
to fertility, blur social boundaries, and re- temporáneos en la Roma del primer siglo se call ancient preliterate peoples prior to culrelacionan con la fertilidad, difuminan los tivation, providing historical continuity of cultic practices. límites sociales y recuerdan a los antiguos pueblos preliterarios anteriores a la agricultura, proporcionando continuidad histórica a las prácticas cultuales.

\section{KEYWORDS}

Clothing; Fasti; Fertility; Nudity; Ovid.
PALABRAS CLAVE

Desnudez; Fasti; fertilidad; Ovidio; vestimenta. 


\section{INTRODUCTION}

Ovid's calendar of Roman religious festivals abounds with images of processional devotees wearing spotless garments, accompanied by worshippers en masse either clothed in a specific colour or appearing naked. This ritualistic nudity in its association with fertility provides a connection across three important spring festivals in Ovid's Fasti: the Lupercalia, the Veneralia and the Floralia. Nudity is a powerful social equaliser and reinforces the identifiable link of these celebrations to ancient religious rites at the time of the foundation of Roman civilisation, during an age when clothing was a clear marker of status under Augustus' lex Iulia. At the very beginning of spring in mid-February, it is men who are naked in the streets and whom seem to possess the power of fertility, related back in ritualistic form to the very foundations of ancient Latium. Outside the context of the baths or a ritual setting, this nudity is viewed with complete disdain. Ovid's multi-aetiological explanation for why the Luperci run naked includes a striking account of undressing, cross-dressing, and dressing for divine reception in association with the Roman deities Bacchus and Faunus. By April 1 , the women are naked, cleansing themselves and then praying for the power of attractiveness as a prelude to fertility. Venus Verticordia's devotees remove golden jewellery from her statue, wash and "reclothe" the goddess before undressing and washing themselves. Naked women offer Fortuna Virilis incense at the baths in the hope that the goddess conceals their physical imperfections from the gaze of men. Types of clothing were usually indicative of female status and morality in Latin literature rather than in legislation. Ovid depicts the role of Roman women in ritual in a way that challenges limitations imposed upon them due to their social status. A final example of ritualistic nudity culminates in the full-flowered celebration of spring by women on stage. The multi-coloured robes of the plebeian Ludi Florales are a powerful identifier in the ritualistic aspect of expression of devotion in a communal and so- 
cial sense through dress and even undress, since prostitutes performed there, and the audience demanded the actresses strip. This multi-layered multi-sensory experience of dressing and undressing of deities and devotees sets the scene for ritualised nudity, which I will argue provides a link between these key fertility festivals. I will evaluate each of these episodes in Ovid's Fasti to determine its treatment of nudity and the action of dressing and undressing, considering religious connotations and sociopolitical implications. The fasti were used to construct and reflect on the changing nature of Roman identity through their celebrations. We see a transition from naked men with penetrative powers of fertility over likely partially naked women, to naked women bathing whilst avoiding the gaze of men then transforming themselves into objects of desire and a final climax of sexually charged female nudity on stage. Strong connections have previously been made between the rites of Venus Verticordia, Fortuna Virilis, and the Floralia, on the basis of public nudity and its contexts, but I expostulate that we can extend this to include the Lupercalia. ${ }^{1}$ The sole example of ritualistic nudity of men in the Fasti, strengthened by the celebration of fertility provides connections between the Lupercalia, the Veneralia, and the Floralia.

\section{LUPERCALIA}

In the Lupercalia ritual and its association with Romulus and Remus, the link between ritualistic nudity and fertility in the context of religious identity is interwoven with the origins of Rome. Augustus saw the lex Iulia as a way of reconnecting with Rome's ancestral practices. ${ }^{2}$ Festival and legislation serve as a link between the past and the future here as in they do in the lex Iulia and the Secular games. ${ }^{3}$ The great emphasis on nudity challenges the Augustan drive for moral order based on social distinction established by the clothing Romans wear and so questions the socio-political order of the Augustan moral code. Augustus even established the genital "hip-mantle" as his definitive heroic uniform in his own statuary, moving away from a totally nude depiction. ${ }^{4}$ When Augustus threw off his toga and exposed his chest, this was viewed as a desperate act of begging. ${ }^{5}$ Augustus' legislation and insistence on the toga is par-

1. Pasco-Pranger, 2019, pp. 217-249.

2. Res Gestae VIII 5.

3. Milnor, 2007, pp. 10-11.

4. Wallace-Hadrill, 2008, p. 54.

5. Suet., Aug. 52. 
ticularly worth considering when reading the following passage and noting Ovid's insistence on nudity: ${ }^{6}$

cur igitur currant, et cur (sic currere mos est)

nuda ferant posita corpora veste, rogas?

ipse deus velox discurrere gaudet in altis

montibus et subitas concipit ipse fugas;

ipse deus nudus nudos iubet ire ministros,

nec satis ad cursus commoda vestis erat. ${ }^{7}$

"Why then do they run, you ask? And why (is it their custom to run in this way) with clothes taken off, they bare their bodies naked? The god himself enjoys running swiftly in the high mountains, and to take up sudden flight. The god himself, naked, bids his ministers to go naked; and clothes are not suitable enough for running”.

There is an overwhelmingly positive consideration of public nudity, emphasised by gaudet and the unencumbered nature of the running, and perhaps wellconsidered by Ovid against the backdrop of Augustus' moral code (285). The first explanation given for the naked running in this initial aetiology is simply that nec satis ad cursus commoda vestis erat, yet there are salient features which emerge upon further examination (288). The Luperci are naked in keeping with the rustic nature of the deity Faunus here, deeply embedded in a high mountainous domain. The sudden flight and the running itself are suggestive of Bacchic revelry among the mountains, perhaps even a literary memory of Rome's idealised bucolic origins, a vaguely sentimental and nostalgic yearning for simpler times. The nudity of the Lupercalia also provides a link to the cultic historicity of the festival and so nudity in an accepted context, but its force is nonetheless identifiable. The Lupercalia, with its many aetiologies, seems to me to sit very well with Beard's reasoning in her study of the Parilia; that it is this very nature of such festivals to reinvent or reinterpret themselves which not only ensures their longevity and relevance but their contribution to creating a picture of Romanness via their links with a combination of real and imagined Roman history. ${ }^{8}$ The lengthy explanation of the four varied aetiologies is structurally interesting if we view the entire episode as a narrative arc driven by the necessity of the nakedness of the devotees. At almost symmetrical

\footnotetext{
6. Suet., Aug. 40, 5.

7. Ov., Fast. II 283-288 (all translations are my own, unless otherwise indicated).

8. Beard, 1987, p. 7.
} 
points we have the god in control, bidding ipse deus nudus nudos iubet ire ministros and summoning them naked et nudos ad sua sacra vocat $(287,358)$. At the climatic point of the whole episode around line 344 we see the god come unstuck, fooled by the exchange of clothing, the object of a comedic farce. Although comical, clothing here has a negative consequence for the god and leaves a lasting impression which has a profound effect on the ritual of the Lupercalia.

The link between religious identity and nudity takes centre stage since much of Ovid's discussion of this religious celebration is an explanation of why the Luperci run naked. That they are naked is clear immediately in the introduction to the first aetiology, an indication of what will be a major focus throughout:

Tertia post Idus nudos aurora Lupercos

aspicit, et Fauni sacra bicornis eunt.

dicite, Pierides, sacrorum quae sit origo,

attigerint Lati as unde petita domos. ${ }^{9}$

"The third dawn after the Ides sees the naked Luperci, And the rites of two-horned Faunus take place. Tell me, Pierides, what is the origin of the rites, and from where were they brought to reach the homes of Latium?".

Ovid gives prominence and legitimacy to the rites of Faunus enacted by the naked Luperci, priests of the festival, with his invocation of the Muse dicite, Pierides, sacrorum quae sit origo (269). Hallet rightly suggests that public nudity outside of the baths was unthinkable and the punishment and humiliation to which condemned criminals were relegated, but he then goes on to argue that nudus did not mean completely naked. ${ }^{10}$ The examples Hallet cites for $n u d u s$ to mean including some type of undergarment in general are not in the context of ritual and he himself acknowledges that sources include the Luperci either naked or girt with a loincloth. Ovid emphasises nudity in the four aetiologies he provides for the Lupercalia and it is not until May that the loin cloths are mentioned. Interestingly, here it is also out of the context of the actual celebration day in his calendar that the emphasis is on purification rather than fertility:

et matri et vati paret Nonacrius heros inque peregrina constitit hospes humo, sacraque multa quidem sed Fauni prima bicornis

9. Ov., Fast. II 267-270.

10. Hallet, 2005, p. 61. 
has docuit gentes alipedisque dei.

semicaper, coleris cinctutis, Faune, Lupercis,

cum lustrant celebres vellera secta vias. ${ }^{11}$

"The Nonacrian hero obeys her as both mother and prophet, and stood firm the alien soil's guest. He taught to these clans many sacred rites indeed, but the first were of twohorned Faunus and the wing-footed god. Half-goat Faunus, the Luperci in their loincloths worship you when with their cut hide strips purify the crowded streets".

Dionysus of Halicarnassus cites Aelius Tubero as stating that youths ran around the village naked but for their loins girt with the skin of the victims just sacrificed as a traditional purification of the villagers. ${ }^{12}$ Although Michels argues that the Lupercalia was originally a purification rite, he concedes that the fertility aspect over time became the focus, and acknowledges that ancient and modern authors do see the fertility aspect as central over purification. ${ }^{13}$ Ovid resolves the issue of purification versus fertility by having the women only as recipients of the flagellation. Fertility is the focus here which is further emphasised by the realisation of its effectiveness when the Sabine women have become mothers, and together with their offspring the "remedy for the divided state" stopped opposing forces with the outstretched arms of their grandchildren. ${ }^{14}$ The very fact that Ovid offers alternatives in such detail has been seen as the poet undermining his intent to honour the emperor. ${ }^{15}$ The poet uses the rare word cinctuti to describe the attire of the Luperci, meaning "wearing the cinctus". ${ }^{16}$ Prior to Augustus' revival, ${ }^{17}$ the Luperci were naked and even though Ovid concedes the wearing of the loincloths eventually, earlier in the Fasti his repeated use of the word nudus could suggest a mocking of the emperor's moral programme. Ovid includes the ancient rite of the Lupercalia in the Fasti but seems reluctant to whole-heartedly embrace the restraint and censure of this new moral age. What may have been an ancient pastoral rite was adapted for the city and became an exciting public occasion at which large crowds gathered. ${ }^{18}$ So, our series of festivals in which

11. Ov., Fast. V 97-102.

12. Dion. Hal., $A R$ I $80,1$.

13. Michels, 1953, pp. 36-47.

14. Ov., Fast. III 203-204 and III 217-223. Cf. Takács, 2008, loc. 1081.

15. Newlands, 2006, p. 359.

16. Ov., Fast. V 101.

17. Suet., Aug. 31.

18. Scullard, 1981, p. 78. 
nudity and fertility feature, begins with this popular celebration and ends later with the Floralia, not only popular, but explicitly plebeian.

Ovid employs Arcadian imagery in the initial aetiology of the Lupercalia, rewriting the mythology for a Roman context and further connecting the contemporary practice to its ancient and pastoral origins:

ante Iovem genitum terras habuisse feruntur

Arcades, et luna gens prior illa fuit.

vita feris similis, nullos agitata per usus:

artis adhuc expers et rude volgus erat.

pro domibus frondes norant, pro frugibus herbas,

nectar erat palmis hausta duabus aqua.

nullus anhelabat sub adunco vomere taurus,

nulla sub imperio terra colentis erat:

nullus adhuc erat usus equi, se quisque ferebat:

ibat ovis lana corpus amicta sua.

sub Iove durabant et corpora nuda gerebant

docta graves imbres et tolerare Notos.

nunc quoque detecti referunt monumenta vetusti

moris et antiquas testificantur opes. ${ }^{19}$

"They say the Arcadians held the earth before Jupiter was born: that race existed before the moon. Life was like that of wild beasts, driven by no custom. The people were as yet devoid of practical skills, and primitive. They knew leafy boughs for houses, herbs for crops. Nectar was water drawn up with two palms. No bull panted under curved ploughshare; no land was under control of cultivation. As yet there was no use of the horse; everyone carried themselves, the sheep walked with its body clothed with its own wool. They hardened under Jove and bore their naked bodies, taught to endure heavy rains and south winds. Unclothed now too, they convey a memorial of the old way, and testify to the resources of ancient times".

Ritualistic and charter elements also emerge in the aetiology with its evocation of a much earlier socio-cultural context, in remembrance of the ancient Arcadian worship of Pan, a god Evander brought with him. Zanker argues that Augustus employed visual imagery focussing on the fertility of the bucolic landscape and appropriated Greek mythological imagery in his cultural renewal as symbols of Augustan abundance. ${ }^{20}$ This reminiscence of ancient naked preliterate primitive people prior to cul-

19. Ov., Fast. II 289-302.

20. Zanker, 1998, pp. 173-174.

ARYS, 18, 2020 [347-374] ISSN 1575-166x 
tivation, even before the birth of Jupiter, without skills and custom, an idealised one and evocative of the Saturnian Golden Age, further emphasises clothing as a marker of civilisation which is removed in the worship of such a deity. Despite the later wearing of goatskin loincloths in Book 5, the persistence of nudity here was surely conspicuous to Romans if not forcible to the modern reader. Life without custom is viewed as primitive, vita feris similis, so cultivation and clothing are clearly linked with later civilisation, yet not necessarily things to be desired given Faunus' experience of them here (291). The prospect of remembering ancient practices, resources and times is important since peoples necessarily need to acknowledge and celebrate their past and its traditions to reaffirm their identity, and for Ovid, nudity is an integral part of this memory.

Nudity is a requirement of the ritual runners in Ovid's second aetiology, the $L u$ perci, because an exchange of clothing fooled the god, Faunus. Nudity is the solution, clothes must be removed, calling to mind the removal of clothes in the lavatio rituals of the Veneralia and the nudity of the Floralia. In the Faunus-Omphale episode, the rustic deity abandons his natural and unrefined world of the montana numina in favour of refined, well-dressed civilisation:

sed cur praecipue fugiat velamina Faunus, traditur antiqui fabula plena ioci.

forte comes dominae iuvenis Tirynthius ibat:

vidit ab excelso Faunus utrumque iugo.

vidit et incaluit, 'montana' que 'numina', dixit

'nil mihi vobiscum est: hic meus ardor erit'.

ibat odoratis humeros perfusa capillis

Maeonis aurato conspicienda sinu:

aurea pellebant tepidos umbracula soles,

quae tamen Herculeae sustinuere manus,

iam Bacchi nemus et Tmoli vineta tenebat,

Hesperos et fusco roscidus ibat equo.

antra subit tofis laqueata et pumice vivo;

garrulus in primo limine rivus erat.

dumque parant epulas potandaque vina ministri,

cultibus Alciden instruit illa suis.

dat tenuis tunicas Gaetulo murice tinctas,

dat teretem zonam, qua m odo cincta fuit.

ventre minor zona est; tunicarum vincla relaxat,

ut posset magnas exeruisse manus,

fregerat armillas non illa ad brachia factas,

scindebant magni vincula parva pedes. 
ipsa capit clavamque gravem spoliumque leonis

conditaque in pharetra tela minora sua.

sic epulis functi sic dant sua corpora somno,

et positis iuxta secubuere toris;

causa, repertori vitis quia sacra parabant,

quae facerent pure, cum foret orta dies. ${ }^{21}$

"But why Faunus especially shuns clothes, handed down is a story complete with an ancient joke. By chance, the Tirynthian youth was walking accompanying his mistress. Faunus saw the pair both all the way from high. He saw them and became hot. 'Mountain deities', he said, 'you are nothing to me. This is my flame'. The Maeonian walked, her scented hair streamed her shoulders, with golden bosom to gaze upon. A golden parasol banished the warm sunbeams; and yet, held up by the hands of Hercules. Just now she reached the grove of Bacchus and Timolus' vineyards, and dewy Hesperus rode his dusky horse. She enters a cave panelled with tufa and living pumice, a babbling brook right at the beginning of the threshold. While servants prepare the banquet and the wine to drink, she furnished Alcides with her own clothing. She hands over the delicate tunics dyed with Gaetulian purple; she hands over her smooth girdle which just measured round her own waist. The girdle is too small for his belly; he loosened the fastenings of the tunics, so that he is able to thrust out his great hands, he had shattered the bracelets not made for those arms, his great feet split the little sandal-straps. She herself takes the heavy club and lion spoil and stored the smaller shafts in their quiver. In this way they enjoy the feast, in this way they give their bodies to sleep. And they lay apart, on beds placed near together. The reason, because they were preparing rites for the vine's inventor, they would perform them pure, when the day had arisen".

In preparation for the Bacchic rites, rites of a god himself seen as a transgressor, we see Hercules too as a transgressor of behaviour and of realms. ${ }^{22}$ Note the undressing and redressing motif, with which I will draw thematic connections to the later Venus Verticordia and Fortuna Virilis. In the exchange of clothes, Omphale has not only confused genders, but much like the women of the Veneralia, also removed the markers of her status. Faunus was as confused by clothing and adornment as markers of class and status as Roman men were by women in the street, making this episode is a fitting prelude to the aetiology of the later celebration, the Floralia. A sensory landscape prefaces the climax and ritual consequence of the failed rape, Faunus' heat of sexual anticipation, Omphales' perfumed hair, her gilded bosom and the accessory of the golden parasol held by Hercules, a visual metaphor for his role as the queen's

21. Ov., Fast. II 303-330.

22. Näsström, 2003, p. 140.

ARYS, 18, 2020 [347-374] ISSN 1575-166x 
slave. ${ }^{23}$ Ovid describes the clothing of the devotees of Bacchus here in great detail, recalling when Faunus first sets sights on them, during their exchange of attire and then when Faunus gropes around feeling for Omphale in the dark:

ut tetigit fulvi saetis hirsuta leonis

vellera, pertimuit sustinuitque manum

attonitusque metu rediit, ut saepe viator

turbatus viso rettulit angue pedem,

inde tori, qui iunctus erat, velamina tangit

mollia, mendaci decipiturque nota. ${ }^{24}$

"As he touched the tawny lion pelt bristly with hairs, he was greatly frightened and checked his hand. And terrified, he recoiled in fear, as a traveller often bears back agitated when he sees a snake afoot. Then he touches the soft clothing of the bed which was a adjoining, and is deceived by the lying impression".

The delicate nature of Omphale's couch drapery, mollia to the touch, the bracelets and sandals broken by Hercules' pure physicality itself evinces a form of ineffective bondage. For her, it is the weight of the accessory of the club and the indelicate texture of the lion's skin. The animal skin is hirsuta and so deceives the god who is likewise fooled by the soft coverings of Hercules' couch. The exchange of clothes and the juxtaposition of the rough with the soft here heightens the sensory impact of this scene for both the devotees of Bacchus and the deity. Fantham suggests that this episode derives from mime and I would like to take this one step further and argue that the act of undressing and dressing here possesses both comical and salacious elements in common with the theatrical striptease at the Floralia. ${ }^{25}$ Deceptive clothing heightens comic value in this episode, which then accounts for the required nudity in the rites of the god:

veste deus lusus fallentes lumina vestes

non amat et nudos ad sua sacra vocat. ${ }^{26}$

"The god fooled by clothing, does not like clothes which deceive the eyes, and to his own rites he summons them naked".

23. Littlewood, 1975, p. 1065.

24. Ov., Fast. II 339-344.

25. Fantham, 2002, p. 219.

26. Ov., Fast. II 357-358.

ARYS, 18, 2020 [347-374] ISSN 1575-166X 
The lasciviousness of this aetiology ensures the nudity of the Luperci will not be forgotten. ${ }^{27}$ Ultimately, we see that the removal and exchange of clothing has prevented the rape, and male dominance does not overpower the feminine in this act of failed forced reproduction. This allows us to identify connections to other episodes in the Fasti where undressing, dressing and nakedness form a key element in the ritualistic celebration of a deity during spring when fertility is an important focus. The use of setting and preparatory rites in the celebration of Bacchus is intimately connected to several aspects of the rites of Faunus. If we view the rites of Bacchus and the expected cathartic relief as a prelude to the total abandonment of clothing of devotees in honour of Venus Verticordia and then Fortuna Virilis, we can acknowledge the emergence of a pattern of setting and worship of deities fulfilling a social function by providing oppressed women with licensed and reasonably controlled outlets for frustration. Most Roman women were under the guardianship of men for their entire lives and were discriminated against, particularly under the lex Iulia de adulteriis. ${ }^{28}$ A woman must be divorced and prosecuted, whereas a man only would be if caught with another man's wife. References in the work of Roman poets have been taken to infer that convicted adulteresses were required to wear the toga of prostitutes. ${ }^{29}$ The lex Iulia de maritandis ordinibus, aimed at keeping marriage within and between the classes, also contained women in a physical sense. Clothing and identity provide an important link in relationship between devotees and deities. Omphale's social class is made clear in the further description of her clothing and accoutrements, delicate tunics of Gaetulian purple and bracelets. The "delicate tunics" (tenuis tunicas, 319) may hint at the controversial see-through Coan silk, worn by both matrons and prostitutes. ${ }^{30}$ Since clothing was ideally a reflection of a woman's rank, status and morality, the fashion for Coan silk among matrons confused sartorial, moral and social boundaries. ${ }^{31}$ Ovid's choice here is suggestive of a further blurring of not only the boundaries based on clothing as a marker of status, but morals, since the wearing of such thin garments likened a woman to a prostitute who might wear them, or even appear naked. This is somewhat ironic, given the setting calls for abstinence, but ultimately appropriate considering Faunus' intentions. Despite the Arcadian nature of the Omphale-Hercules-Faunus scene, inferences can still be made

27. Newlands, 1995, p. 60.

28. Gardner, 1986, pp. 15-18 and 252-255.

29. Mart., II 39 and X 52; Iuv., II 68; Hor., Serm. I 2, 63; Cic., Phil. II 44; Mart., VI 64, 4; Tib., III 16, 3.

30. Hor., Sat. I 2, 101-102; Prop., I 2, 2; II 1, 5-6; IV 2, 23; Sen., Helv. XVI 4; Ben. VII 9, 5.

31. Olson, 2002, p. 398. 
about the bracelets of adornment. Ovid, who warned against excessive adornment, includes jewellery in this episode, and we will consider such adornment further when discussing the Veneralia. ${ }^{32}$ Berg argues that impressive gold jewellery was morally restricted according to the nobilitas of the wearer and that worn by a senatorial woman would indicate dignitas, but by a freedwoman, reprehensible luxuria. ${ }^{33}$ Matrons were actually not only attracted to the wearing of Coan silk, but also jewellery, despite the negative moral implications and blurring of social status lines associated with such adornment. Women could choose to wear colours such as purple and gold and were free to do so, expressing some form of agency through dress. ${ }^{34}$ In the worship of the goddess, however, the jewellery becomes sacred and does not possess the negative connotations it has in some works of Ovid and those of Seneca. In the queen, we have a case for sartorial confusion, not limited to the cross-dressing, but in the delicate tunics and the gold bracelets, both of which are removed.

Ovid's third aetiology for the nudity during the rites of Faunus on this day includes an invocation to Juno for fertility and gentle birth for the Italian matrons. Romulus has carried off the Sabine women, but does not possess the procreative power to ensure offspring and continuation of the race, so he must turn to the mighty female goddess Juno. Female intervention is required to secure fertility and continuity of the Roman race from its very beginnings.

monte sub Esquilio multis incaeduus annis

Iunonis magnae nomine lucus erat.

huc ubi venerunt, pariter nuptaeque virique

suppliciter posito procubuere genu,

cum subito motae tremuere cacumina silvae

et dea per lucos mira locuta suos:

'Italidas matres' inquit 'sacer hircus inito'.

obstipuit dubio territa turba sono.

augur erat (nomen longis intercidit annis,

nuper ab Etrusca venerat exul humo),

ille caprum mactat, iussae sua terga puellae

pellibus exsectis percutienda dabant,

luna resumebat decimo nova cornua motu,

virque pater subito nuptaque mater erat.

gratia Lucinae! dedit haec tibi nomina lucus,

32. Ov., Ars am. III 129-132.

33. Berg, 2002, p. 47.

34. Harlow, 2012b, p. 38.

ARYS, 18, 2020 [347-374] ISSN 1575-166X 
aut quia principium tu, dea, lucis habes, parce, precor, gravidis, facilis Lucina, puellis maturumque utero molliter aufer onus. ${ }^{35}$

"Beneath the Esquiline mount there was a sacred grove, uncut in many years, named for mighty Juno. When they had come to this place, brides and husbands alike suppliantly fell down on bended knee: when suddenly the forest shook and treetops trembled, and the goddess spoke wonders through her own sacred grove: 'Italian matrons' she said 'let the sacred goat enter.' The terrified crowd was numbed by the dubious utterance. There was an augur (whose name had been lost by the long years) recently an exile come from Etruscan soil. That man sacrifices a he-goat. As ordered, the girls offered their backs to be struck through and through by strips from its hide. In her tenth motion the moon was taking up new horns, the husband was suddenly a father, and the bride a mother. Thanks to Lucina! The grove gave this name to you, or because you, goddess, have the beginning of the light. Kind Lucina, have mercy upon, I pray, pregnant girls, and gently remove the ripe burden from the womb".

This passage introduces strips cut from the sacrificial goat to be used as whips. The force here suggests that women were whipped to the point of skin breaking, allowing the he-goat to "enter" (445-446).$^{36}$ In addition to strengthening the link between ritualistic nudity and fertility, is also suggestive of the women's backs being naked or exposed in some way to receive the whip and its potency, a fuller or more literal adherence to the words of the goddess. Plutarch extrapolates this to accessories with which the Luperci run the streets to the same effect. The historian highlights the fertility aspect of this festival when he states that "noble youths and of the magistrates" ran through the city striking "women of rank" with "shaggy thongs" hoping for pregnancy and easy delivery if already pregnant. ${ }^{37}$ Plutarch is writing much later when it seems the girt loins were entrenched in the festival, which also only included women of high status. Emphasis is on the victim to be adopted as part of the dress of the devotees and even used as an accessory in the ritual aspect of the flagellation. Augustus' moral programme was designed to contain women, in connection with its aim to raise the birth-rate, since during the civil war period, a whole class of male nobility was lost while the majority of its women survived. ${ }^{38}$ Not only has Ovid taken care to include all the aetiologies, but he has chosen this festival in which to em-

35. Ov., Fast. II 435-452.

36. Wiseman, 1995, p. 14.

37. Plut., Vit. Caes. 61, 1-4.

38. Holleman, 1973, p. 260; Syme, 1952, p. 414. 
phasise public nudity of men, despite the implications of the Augustan reformation, which included laws designed to ensure legitimate offspring in response to the devastating effects of the civil war on the population. The marriage and adultery laws, in reality, adversely affected women disproportionately, and in Ovid's use of female nudity throughout the Fasti we can see a release from those restrictions in a ritual setting, beginning here with their exposed backs. When considered with Plutarch's description following the Lupercalia, of Caesar denying the golden crown from atop a golden throne on the rostra, we understand a politically motivated attempt to appropriate an ancient fertility festival associated with the foundation of Rome. The continuity of the Roman race is ensured via the accoutrement of the whips, in which Faunus and the Luperci play an important part.

In the fourth and final aetiology, Ovid gives the Roman causa for the nudity of the Luperci emphasis by placing it in a central panel when we view the Lupercalia description in its entirety (2.267-474). Augustus restored the rites of the Lupercalia and Ovid "stresses the continuity of ritual practice within a framework of social change". ${ }^{39}$ The emphasis on nudity then is explicably bound with Ovid's contribution to reflecting on the identity of Romanness during a time when Augustus is making drastic changes ${ }^{40}$ which might require an approach with greater propriety. Yet, Ovid's patriotic intentions are undeniable:

adde peregrinis causas, mea Musa, Latinas, inque suo noster pulvere currat equus, cornipedi Fauno caesa de more capella venit ad exiguas turba vocata dapes, dumque sacerdotes veribus transuta salignis exta parant, medias sole tenente vias, Romulus et frater pastoralisque iuventus solibus et campo corpora nuda dabant; caestibus et iaculis et misso pondere saxi brachia per lusus experienda dabant: pastor ab excelso "per devia rura iuvencos, Romule, praedones, et Reme", dixit "agunt". longum erat armari: diversis exit uterque partibus; occursu praeda recepta Remi. ut rediit, veribus stridentia detrahit exta atque ait "haec certe non nisi victor edet".

39. Harries, 1991, p. 164.

40. Feeney, 2006, p. 471. 
dicta facit Fabiique simul, venit inritus illuc

Romulus et mensas ossaque nuda videt;

risit et indoluit Fabios potuisse Remumque

vincere, Quintilios non potuisse suos.

fama manet facti: posito velamine currunt,

et memorem famam, quod bene cessit, habet. ${ }^{41}$

"Add Latin causes to the foreign, my Muse, and let my horse run in its own dust. To horn-footed Faunus, according to custom, a she-goat had been slaughtered and a crowd came, summoned to the meagre feast. While the priests prepare the entrails, pierced through on spits of willow-wood, the sun held mid-way. Romulus and his brother and the young shepherds were offering their naked bodies to the sunlit field. With loaded strips of hide and javelins and with the weight of thrown stones, their arms they gave to the test through sport. A shepherd shouted all the way from high, 'Romulus! Remus!' he said. 'Robbers are driving the young bullocks out of the way of the fields.' It would take too long to arm. Each of them go forth, divided in different directions; Remus runs into them, and the plunder is recovered. When returned, he takes down the hissing entrails from the spits and says: 'None but the victor shall eat these for certain.' He does as he said, and the Fabii do too. Romulus comes there with nothing and sees the bare tables and bones. He laughed, and was grieved the Fabii and Remus had been able to win, and his own Quintilii had not been able. The report of the deed remains: they run without clothes, because it resulted well it has enduring fame".

The poet elevates this aiton when he evokes his Muse for the second time adde peregrinis causas, mea Musa, Latinas (359). The god Faunus is honoured in a way truly worthy of respect in the context of Roman history. ${ }^{42}$ Furthermore, Ovid also explains the origins of the two colleges of the Luperci, the Quinctiales and the Fabiani, created to commemorate the companions of Romulus and Remus, the Quintilii and the Fabii (377-378). Ovid highlights the contribution of these ancient, yet still contemporarily important families, to the Roman memory. ${ }^{43}$ In doing so, ensuring the importance of nudity at this fertility ritual receives attention as an instrumental feature. In the face of the Augustan moral code, Ovid appears determined to keep the Luperci naked, and through this aspect, maintains the continuity of this ancient ritual practice and its contribution to Romanness not only in his time, but in the future.

41. Ov., Fast. II 359-380.

42. Parker, 1993, p. 206.

43. Fabre-Serris, 2013, pp. 89-90. 


\section{VENERALIA}

Ovid blurs the social status of women participating in the Veneralia by inviting them in an ambiguous manner, one quite open to an interpretation which includes all classes, and then also by ensuring they are naked for both rituals. There is no mention of chaste Sulpicia or the transgressions of the Vestal Virgins, Ovid's Venus rather, is introduced with rich associations to fertility of all, the bringer of life. Champeaux argues that these rites have at their core the objective of coitus and I further contend that fertility is the essential end of such engagement, towards which the festival is actually directed. ${ }^{44}$ Despite the lack of extant evidence about legislation on women's dress, even within the lex Iulia de adulteriis, women guilty of adultery supposedly wore the toga, the traditional dress of prostitutes, rather than the matronly stola. Moral legislation on marriage and adultery lay at the core of the emperor's programme of social control and emphasised definition and maintenance of status and distinctions, encouraging status-appropriate behaviour. ${ }^{45}$ Augustan clothing was an important marker of status and virtue for women by which they would be identified as matrons, young wives, prostitutes and so on, in many of these festivals. ${ }^{46}$ Just as the toga was for men, the stola was the mark of married female Roman citizens. ${ }^{47}$ If not legislated, it was still a public sign of status which is interpreted as a form of social division and control. This is further notable when, in some of the rituals, Romans are required to abandon their clothing and appear naked, stripped of easy social identification. Nudity challenges the social hierarchy. Ovid "undermines the dress code of the Augustan legislation ... whereas cults of traditional Roman religion tended to reinforce social hierarchies". ${ }^{48}$ We see this in Ovid's depiction of the cult of Venus Verticordia, which includes the participation of women of varied status together in the one rite:

rite deam colitis, Latiae matresque nurusque

et vos, quis vittae longaque vestis abest.

aurea marmoreo redimicula demite collo,

demite divitias: tota lavanda dea est.

aurea siccato redimicula reddite collo:

nunc alii flores, nunc nova danda rosa est.

44. Champeaux, 1982, pp. 378-395.

45. McGinn, 2008, pp. 1 and 3.

46. Ov., Ars am. III 483: vittae honore; Rem. am. 386; Val. Max., V 2, 1.

47. Edmondson, 2008b, p. 24.

48. Ziogas, 2014, pp. 735, 741.

ARYS, 18, 2020 [347-374] ISSN 1575-166X 
vos quoque sub viridi myrto iubet ipsa lavari: causaque, cur iubeat (discite!), certa subest litore siccabat rorantes nuda capillos:

viderunt satyri, turba proterva, deam. sensit et opposita texit sua corpora myrto: tuta fuit facto vosque referre iubet. ${ }^{49}$

"Duly worship the goddess, Latin matrons and brides, and you who leave off the fillets and long gown. Take off from her marble neck the golden necklaces, take off her wealth; the goddess is washed whole. Return the golden necklaces to her dried neck, now other flowers, now a new rose is given. The goddess herself orders you too to be washed, under green myrtle, the reason why she orders, (Learn it!), is certain. She was naked drying her dripping hair on the shore. Satyrs saw, a wanton band, the goddess. She realised and covered her body by placing myrtle against it. By doing this she was safe, and she orders you repeat it".

In honour of Venus Verticordia, goddess and then worshippers are naked in a lavatio ritual. So far, it has been the men naked but here we witness a ritual where the female devotees appear naked. Clothed "matrons" matres, "young brides" nurus and "who leave off the fillets and long robe" quis vittae longaque vestis abest (other women) of Latium, remove the deity's accessories of jewellery and flowers, wash her statue, redress the goddess and then they undress to wash themselves. The longa vestis is identified with the stola of the matron, who was in a legitimate marriage and expected to be modest and faithful. ${ }^{50}$ Ovid's inclusion of women who do not wear the fillets (or headbands) and the stola is ambiguous and open for inclusion of even more women than may be first anticipated. It might include matrons who choose not to wear them, poor women who do not, or even women unlikely to wear them due to their professions, such as those working in various situations, not solely limited to prostitution. Ovid summons these women, often identified by their dress, and seemingly includes all women in a rite which then demands nudity, and strips them of easy social identification. The inclusive approach is interesting given Ovid's own prescriptive approach to female clothing and adornment. ${ }^{51}$ Removal of clothing in the Fasti negates the sartorial confusion which seemed an anxiety of Roman men. The action of undressing and redressing the statue of Venus Verticordia and then her devotees also recalls the Hercules and Omphale episode. Ovid emphasises the ornaments of

49. Ov., Fast. IV 133-144.

50. Ov., Ars am. I 31-32; Mart., I 35.

51. Ov., Ars am. III.

ARYS, 18, 2020 [347-374] ISSN 1575-166x 
the goddess, as he did for Queen Omphale the devotee. The association with wealth, acknowledged earlier in the description of the queen, is clear in the interaction with the iconography in the more socially inclusive Venus Verticordia, where the goddess' wealth, represented by her golden necklaces, is removed. The accessory of jewellery in both examples, and especially in the ritualisation of it in the Venus Verticordia, serves as an identifier of wealth in the devotee Omphale, and reverence in the deity. Elegance, which includes clothing and adornment, and cleanliness, were signs of the upper classes. ${ }^{52}$ Nudity, devoid of clothing and ornamentation becomes a temporary social equaliser for women, eliminating visual markers of status.

Nudity ensures that markers of status and class are removed as well as any sartorial confusion associated with clothing and adornment. Women who wore clothing not fitting their status, confused the boundaries that the lex Iulia was attempting to exert on the Roman population. ${ }^{53}$ Olson argues that clothing for women in ancient Rome may have been largely prescriptive and so it was not always easy to identify social and moral status using vestimentary indicators. ${ }^{54}$ There is usually a clear affirmation of both social status and identity in the dress of devotees, but in the worship of Venus, we can make a case for women of all social groups. ${ }^{55}$ Nudity was a more dangerous condition for Roman women than it was for their male counterparts. In the context of Roman "public nudity" in the baths for women, the myrtle reminds us that when naked, matrons are no longer afforded the level of protection offered by their sartorial markers. The protective covering of the myrtle, a reminder of Venus' evasion from the satyrs, signals a positive consideration of the episode since the initial threat of rape is extinguished. For Roman women, confined and restricted by expectations of marriage, including pressure to produce offspring, and legal punishment for adultery, in conjunction with Roman distaste of public nudity, ritualistic nudity had the potential to be quite liberating. Venus, surprisingly, encourages chastity, suggestive of an association of nudity with purity after the ritual cleansing of the goddess, which is then juxtaposed with a cosmetic desire to appear attractive to men in the celebration of Fortuna Virilis:

discite nunc, quare Fortunae tura Virili

detis eo, calida qui locus umet aqua.

accipit ille locus posito velamine cunctas

52. Olson, 2008, pp. 25-26.

53. Dixon, 2014, p. 301.

54. Olson, 2006, pp. 181-182.

55. Fantham, 1998, pp. 116-117.

ARYS, 18, 2020 [347-374] ISSN 1575-166X 
et vitium nudi corporis omne videt; ut tegat hoc celetque viros, Fortuna Virilis

praestat et hoc parvo ture rogata facit. ${ }^{56}$

"Now you learn why you give incense to Fortuna Virilis there in that place which is wet with warm water. That place receives all women without their clothes and sees every flaw of the naked body. Where Fortuna Virilis covers this and conceals it from men, and she does this ready to help when asked with a little incense".

"All women" (cunctas) are naked in the worship of Fortuna Virilis in the hope that the goddess conceals the blemishes on their naked bodies from men, which is both interesting and somewhat ironic (148). We might infer from the use of cunctas that this too is a socially inclusive celebration for women of varied status. The consideration of nakedness is ultimately positive since although the women may have blemishes, the goddess will conceal them. Beauty and adornment could be considered symbols of fertility and virtue in association with Venus and nude portraits of Roman matrons. ${ }^{57}$ Nakedness of female devotees is seen as instrumentally crucial in the worship of both Venus Verticordia and Fortuna Virilis. Even the use of incense, in the case of Fortuna Virilis, is suggestive of concealment if one considers its smoke. This idea can be further extrapolated to draw a connection between the use of green myrtle for concealment of the body and the incense performing the same function. In the Lupercalia, the Luperci are instruments of fertility, and in the Veneralia, it is the women themselves who are given control through the conduit of feminine goddesses, cleansing themselves as a prelude to fertile activities. In the Floralia, Ovid realises his vision of religious ritual where women of all classes have been included, from the Lupercalia to this festival, women have played an important role, contra restrictions imposed by Augustan ideology.

\section{Floralia}

In this final example of ritualistic nudity, Ovid affords the involvement of prostitutes in the extremely popular and already inclusive celebration of the plebeian chorused Floralia. Ovid introduces Flora in a similar fashion to the way he introduced Venus, as a goddess with powerful procreative abilities. Flora was not simply a goddess of

56. Ov., Fast. IV 145-150.

57. D’Ambra, 1996, pp. 219-220. 
flowers, but of agriculture and fertility. ${ }^{58}$ Pasco-Pranger posits that there is a suggested connection between nudity and fertility here, given Flora's name and the positioning of the festival during spring. ${ }^{59} \mathrm{In}$ fact, the festival was in response to failing fields, gardens, olives and crops, securing Flora's position as an important goddess of fertility. ${ }^{60}$ In Republican times, Cicero saw the Floralia as most ancient and amongst those festivals at the very heart of Roman identity, an opportunity for the goddesses' benevolence to be cast upon the populus and the plebs. ${ }^{61}$ The Floralia would have been a ritual of integration and social cohesion and one over which the Senate would have been keen to exert influence. ${ }^{62}$ Flora's ludi were funded by the plebeian aediles, the Publicii, who collected fines from the rich grazing their cattle on public land. ${ }^{63}$ Prostitutes and people of the lower classes were given less opportunity to celebrate at festivals than the upper classes, but more licence at those such as the Floralia. Ovid's choice to include prostitutes is striking furthermore due to the lack of mention of meretrices by Verrius Flaccus in the Fasti Praeneste ${ }^{64}$ strongly argued to be Augustan propaganda. ${ }^{65}$ The focus on the Praeneste on fertility of grain and agricultural aspects does support that the connection between the festival and fertility was already well-established, and extrapolating the fertility of the crops and all vegetation to the fertility of women is integral to the very nature of the celebration of spring. Juvenal hints that Roman wives fought as gladiators and according to Valerius Maximus it was custom at theatrical performances for the audience to demand actresses remove their clothes at least by the late Republic. ${ }^{66}$ On a famous occasion in $55 \mathrm{BCE}$, the presence of Marcus Cato in the audience inhibited the usual calls for the striptease. When he realised, he left the theatre and the show went on. This nakedness could be viewed as "a light-hearted patriotic showpiece" of a mime play re-enactment of the Cloelia story, who swam across the river to escape when she asked for permission to bathe in the river without the prying eyes of the guards ${ }^{67}$ Such mimes encouraged further blurring of sartorial lines, but in a controlled environment, since the actresses would have been dressed as characters which often included matrons and Cloelia herself

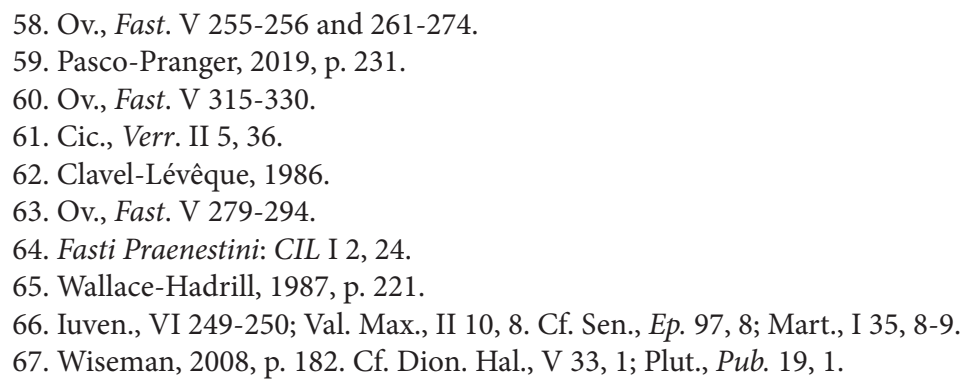


would hardly have been dressed as a prostitute. Earlier we acknowledged the fertility aspect of the Lupercalia in ensuring the continuation of the Roman people, and in the Floralia, we can extrapolate the budding of the flowers to plants whose produce fed them ${ }^{68}$ :

scaena levis decet hanc: non est, mihi credite, non est

illa coturnatas inter habenda deas.

turba quidem cur hos celebret meretricia ludos,

non ex difficili causa petita subest.

non est de tetricis, non est de magna professis,

volt sua plebeio sacra patere choro,

et monet aetatis specie, dum floreat, uti;

contemni spinam, cum cecidere rosae.

cur tamen, ut dantur vestes Cerialibus albae,

sic haec est cultu versicolore decens?

an quia maturis albescit messis aristis,

et color et species floribus omnis inest?

annuit, et motis flores cecidere capillis,

accidere in mensas ut rosa missa solet. ${ }^{69}$

"A light stage is suitable for this goddess. She is not, believe me she is not, to be held among the goddesses in tragic boots. Indeed, why a troupe of prostitutes filled these games, the reason behind this is not difficult to find. She is not from the gloomy, she is not from those who declare public great things. She wants her own rites to be open to a plebeian chorus, and she advises a view to make sense of life, while it blooms. 'The thorn,' she says, 'is despised once the roses have fallen.' Why is it, though, that white robes are given at the Cerialia, so this goddess is fitting in multicoloured clothing? Is it because the harvest whitens when the ears are ripe, and in flowers there is every colour and show? She nodded, and the movement of her hair caused the flowers to fall, just as the thrown rose is accustomed to fall on the tables".

Ovid makes clear the nature of the celebrations earlier in the Fasti "the stage has the manner of freer jest" (scaena ioci morem liberioris habet).$^{70}$ This festival is different in that it is plebeian and one in which prostitutes play a most visible role, as performers. Colourful clothing is a powerful identifier, one which goes beyond the simple aetiology that "in flowers there is every colour and show" (color et species floribus

68. Palmer, 2006, p. 59.

69. Ov., Fast. V 347-360.

70. Ov., Fast. IV 946.

ARYS, 18, 2020 [347-374] ISSN 1575-166x 
omnis inest).$^{71}$ The dress here suits the "greater licentiousness" (lascivia maior) and "light-hearted" (iocosis) nature of the revellers who celebrate this festival. ${ }^{72}$ Ovid may have been a poet particularly concerned with issues of sexuality and desire, ${ }^{73}$ but I do not think this was his sole reason for giving meretrices prominence in the Fasti. Ovid gives prostitutes a prominent role in such a popular and public festival which not only includes, but really elevates them in a cultic sense. These women are included in the Roman religious ritual calendar of events and in such a visible way. Perhaps due to its oftentimes perceived risque reputation, the importance of this spring festival, particularly its contribution to fertility, seems to have been not given the attention deserved in modern scholarship, but this was not always the case in antiquity. The consideration of nudity at this festival is positive, despite the air of disapproval due to its licentiousness, blurring of social distinctions between matrons and prostitutes and the often-highlighted feature of the involvement of prostitutes. The ritualisation of nudity in the Floralia has the same effect for prostitutes as undressing does for other classes of women in the spring festivals already discussed. It invites the audience to see only the nakedness and removes markers of identification. Even if we concede that Ovid does not explicitly refer to nudity, the social status lines are blurred likely more than visually seen on the streets, since much is made of the necessity of colourful clothing as intrinsic to Flora's festival in his explanation. Martial supports this conclusion by suggesting that prostitutes adopted the clothing of matrons: "who clothes the Floralia and grants the modesty of the stola to prostitutes?" (quis Floralia vestit et stolatum permittit meretricibus pudorem?). ${ }^{74}$ Ovid provides us with a view of religious ritual involvement, one which involves women and men of every class and status, and so one which is more realistic in its reflection of society; everyone contributes to the continuation of the Roman state and identity. This passage also offers which might appear at first glance a cursory aetiology for the wearing of white dress at the Cerialia, however, juxtaposition with the Floralia elevates the multi-coloured festival, associates it with fertility and demonstrates the full force of plebeian-centric celebration. Do we acknowledge this as a response to the anxiety-producing tensions of the Roman socio-political reality? ${ }^{75}$ The lex Iulia prescribed what Romans wore, whom they married, and restricted sexual freedom, which served to emphasise social status and restrict movement between the ranks. Ovid has chosen to include women

71. Ov., Fast. V 358.

72. Ov., Fast. V 331 and 183.

73. Strong, 2016, p. 194.

74. Mart., I 35, 8-9.

75. Cels-Saint-Hilaire, 1977, p. 274.

ARYS, 18, 2020 [347-374] ISSN 1575-166X 
nude as a comment on this reality, challenging the marking of women's status on the basis of clothing and he has done so on the public stage in an extremely popular festival. It was in this ritual context that Romans were invited to view the nudity of prostitutes and these women themselves as positive in their contribution to the religious celebration of a goddess concerned with agricultural and human fertility. These women are given access and ensured participation and any ambiguity related to their identification, status and involvement, which may have been present in the previous two festivals, has well and truly been removed. In the Floralia then, Ovid ensures that all women finally have been able to share in religious cultic activities, a form of social equalisation, and it has been in the context of nudity and fertility during important spring festivals.

\section{Conclusion}

Ritualistic nudity and its implications for women and their fertility provides a link between spring festivals the Lupercalia, the Veneralia, and the Floralia. Ovid's inclusive Fasti serves as a calendar which has a clear focus on public nudity in these three festivals where women participate in religious rites in the Augustan age. Religious festivals were occasions for Romans to gather in community groups as devotees in honour of their deities. Ovid provides aetiologies for ancient rites and reshapes them to appeal to his Roman audience in an authentic way, providing historical continuity for these cults which may not always be necessarily in line with Augustan sensibilities. I have considered these examples and argued that there is a link between religious rites intimately connected with nudity and fertility which challenges constructed notions of social identity. We have seen an increasingly accepting and inclusive involvement of women as we have progressed through these festivals, and it has been based on nudity and fertility. Emphasis on nudity of devotees is gender specific to either male or female at these ritual celebrations. In Ovid's description of the Lupercalia, nudity, clothing, and cross-dressing are prominent features in the multi-aetiological explanation for why the Luperci run naked in honour of Faunus, with an overwhelmingly disproportionate emphasis on the nudity of the Luperci. While public nudity was shocking, Ovid has made the most of the ritualistic context to emphasise its contribution to fertility in festivals where women have sanctioned roles. The "flagellator priests" are at least half, if not fully naked, as might be, in part, the women proffering their backs. The emphasis is clearly on the fertility of the women, matrons, and girls, who need to be impregnated by the men. Undressing, redressing, and nudity are key in the lavatio rituals in honour of female deities Venus and Fortuna during the Veneralia. Nudity removes visual markers of women's social class, matrons, brides and 
those who leave off the fillets and long robes in the former and likely all women in the latter. Women wash and screen themselves and then pray for attractiveness, so we see more agency in their role in fertility. Colourful clothing and nudity are clear markers of the accessibility of the Floralia with its prostitute striptease and plebeian chorus, where women seem to have taken charge by flaunting their naked sexuality in a public forum. In a post-civil war world, Augustus' lex Iulia was designed to reinforce Roman civic identity, and clothing was one of the ways in which it attempted to accomplish this goal. Its punishment for adultery, and of those unmarried, and its rewarding of those bearing children, marks the importance of fertility. Ovid's emphasis on nudity at the three major festivals I have discussed invites an increasingly egalitarian approach, since visual markers of clothing as status are removed, allowing women of varied status participation. These ritualistic celebrations afforded opportunity for the reaffirmation of social community, the challenging of social hierarchal assumptions of women based on clothing and ultimately, the tracing back of Roman identity from the earliest of times by providing historical continuity of ancient cultic practices. 


\section{Bibliography}

Beard, M. (1987). A Complex of Times. No More Sheep on Romulus' Birthday. The Cambridge Classical Journal, 33, pp.1-15.

Berg, R.P. (2002). Wearing Wealth. Ornatus and Mundus Muliebris as Status Markers of Women in Imperial Rome. In Setälä, 2002, pp. 15-73.

Boyd, B.W. (ed.) (2002). Brill's Companion to Ovid. Leiden: Brill.

Cels-Saint-Hilaire, J. (1977). Le fonctionnement des Floralia sous la République. Dialogues d'histoire ancienne, 3.1, pp. 253-286.

Champeaux, J. (1982). Fortuna. Le culte de la Fortune à Rome et dans le monde romain, I. Fortuna dans la religion archaïque. Rome: École française de Rome.

Clavel-Lévêque, M. (1986). L'espace des jeux dans le monde Romain : hégémonie, symbolique et pratique sociale. ANRW, 2.16.3, pp. 2405-2563.

D’Ambra, E. (1996). The Calculus of Venus. Nude Portraits of Roman Matrons. In Kampen, 1996, pp. 219-232.

Dixon, J. (2014). Dressing the Adulteress. In Harlow and Nosch, 2014, pp. 298-305.

Edmondson, J. (2008a). Roman Dress and the Fabrics of Roman Culture. Toronto: University of Toronto Press.

Edmondson, J. (2008b). Public Dress and Social Control in Late Republican and Early Imperial Rome. In Edmondson, 2008a, pp. 21-46.

Fabre-Serris, J. (2013). Roman Gentes in Ovid's Fasti. The Fabii and the Claudii. In Farrell and Nelis, 2013, pp. 89-106.

Fantham, E. (ed.) (1998). Ovid. Fasti Book IV. Cambridge: Cambridge University Press.

Fantham, E. (2002). Ovid's Fasti. Politics, History, and Religion. In Boyd, 2002, pp. 197-233.

Faraone, C.A. and McClure, L.K. (eds.) (2006). Prostitutes and Courtesans in the Ancient World. Madison: University of Wisconsin Press.

Faris, S.B. and Lundeen, L.E. (eds.) (2006). Ten Years of the Agnes Kirsopp Lake Michels Lectures at Bryn Mawr College. Bryn Mawr: Thomas Library.

Farrell, J. and Nelis, D.P. (eds.) (2013). Augustan Poetry and the Roman Republic. Oxford: Oxford University Press.

Feeney, D. (2006). Si licet et fas est. Ovid's Fasti and the Problem of Free Speech under the Principate. In Knox, 2006, pp. 464-488.

Gardner, J.F. (1986). Women in Roman Law and Society. Bloomington: Indiana University Press.

Hallett, C.H. (2005). The Roman Nude. Heroic Portrait Statuary 200 BC-AD 300. Oxford: Oxford University Press.

Harlow, M. (ed.) (2012a). Dress and Identity. Oxford: Archaeopress.

Harlow, M. (2012b). Dressing to Please Themselves. Clothing Choices for Roman Women. In Harlow, 2012a, pp. 37-46. 
Harlow, M. and Nosch, M. (eds.) (2014). Greek and Roman Textiles and Dress. An Interdisciplinary Anthology. Oxford: Oxbow Books.

Harries, B. (1991). Ovid and the Fabii: Fasti 2.193-474. The Classical Quarterly, 41.1, pp. 150168.

Holleman, A.W.J. (1973). Ovid and the Lupercalia. Historia: Zeitschrift für Alte Geschichte, 2, pp. 260-268.

Kampen, N. (ed.) (1996). Sexuality in Ancient Art. Near East, Egypt, Greece and Italy. Cambridge: Cambridge University Press.

Knox, P.E. (ed.) (2006). Oxford Readings in Ovid. Oxford: Oxford University Press.

Littlewood, R.J. (1975). Ovid's Lupercalia (Fasti 2.267-452). A Study in the Artistry of the Fasti. Latomus, 34.4, pp. 1060-1072.

McGinn, T. (2008). Something Old, Something New. Augustan Legislation and the Challenge of Social Control. Ancient History Bulletin, 22, pp. 1-32.

Michels, A.K. (1953). January. The Topography and Interpretation of the Lupercalia. Transactions and Proceedings of the American Philological Association, 84, pp. 35-59.

Milnor, K. (2007). Augustus, History, and the Landscape of the Law. Arethusa, 40.1, pp. 7-23.

Näsström, B.M. (2003). The Rites in the Mysteries of Dionysus. The Birth of the Drama. Scripta Instituti Donneriani Aboensis, 18, pp. 139-148.

Newlands, C.E. (1995). Playing with Time. Ovid and the Fasti. Ithaca: Cornell University Press.

Newlands, C. (2006). Ovid's Narrator in the Fasti. In Knox, 2006, pp. 351-369.

Olson, K. (2002). Matrona and Whore. The Clothing of Women in Roman Antiquity. Fashion Theory, 6.4, pp. 387-420.

Olson, K. (2006). Matrona and Whore. Clothing and Definition in Roman Antiquity. In Faraone and McClure, 2006, pp. 186-204.

Olson, K. (2008). Dress and the Roman Woman. Self-presentation and Society. London: Routledge.

Palmer, R. (2006). Flora and the Sibyl. In Faris and Lundeen, 2006, pp. 58-70.

Parker, H.C. (1993). Romani Numen Soli. Faunus in Ovid's Fasti. Transactions of the American Philological Association, 123, pp. 199-217.

Pasco-Pranger, M. (2019). With the Veil Removed Women's Public Nudity in the Early Roman Empire. Classical Antiquity, 38.2, pp. 217-249.

Scullard, H.H. (1981). Festivals and Ceremonies of the Roman Republic. Ithaca: Cornell University Press.

Setälä, P. (2002). Women, Wealth, and Power in the Roman Empire. Rome: Institutum Romanum Finlandiae.

Strong, A.K. (2016). Prostitutes and Matrons in the Roman World. Cambridge: Cambridge University Press.

Syme, R. (1952). The Roman Revolution. Oxford: Oxford University Press.

Takács, S.A. (2008). Vestal Virgins, Sibyls, and Matrons. Women in Roman Religion. Austin: University of Texas Press. 
Wallace-Hadrill, A. (1987). Time for Augustus. Ovid, Augustus and the Fasti. In Whitby and Bramble, 1987, pp. 221-230.

Wallace-Hadrill, A. (2008). Rome's Cultural Revolution. Cambridge: Cambridge University Press.

Whitby, M. and Bramble, J.C. (eds.). Homo Viator. Classical Essays for John Bramble. Bristol: Bristol Classical Press.

Wiseman, T.P. (1995). The God of the Lupercal. Journal of Roman Studies, 85, pp. 1-22.

Wiseman, T.P. (2008). Unwritten Rome. Exeter: University of Exeter Press.

Zanker, P. (1988). The Power of Images in the Age of Augustus. Ann Arbor: University of Michigan Press.

Ziogas, I. (2014). Stripping the Roman ladies: Ovid's Rites and Readers. The Classical Quarterly, 64.2, pp. 735-744. 